\title{
On-Farm Demonstration and Evaluation of Improved Plastic Milk Churner in West Arsi Zone of Oromia Regional State, Ethiopia
}

\author{
Fetiya Mohammed, Estefanos Tadesse, Tesfaye Gemechu \\ Oromia Agricultural Research institute Adami Tulu Agricultural Research Center
}

\begin{abstract}
The study was conducted in two districts of West Arsi zone with an objective of demonstrating and evaluating improved plastic milk churner there by reducing women's workload in churning activity. 17 improved plastic milk churners were distributed and evaluated by participating women farmers grouped in farmer's research groups (FRGs). The results showed a significant difference in time of churning at $(p<0.05)$

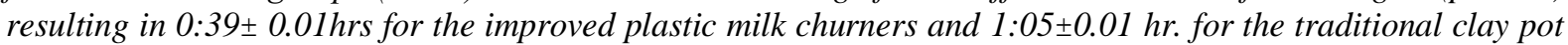
churners. However, there was no statistically significant difference on butter yield between the churners in the study areas. Nevertheless, the improved plastic churner were found to be more time saving than the traditional clay pot churners and are recommended for further scaling up works.
\end{abstract}

Keywords: Milk Churner, FRG.

\section{INTRODUCTION}

Milk production and processing is an important activity of small holder farmers in Ethiopia. However, a fraction of total milk production enters the formal processing channel. Thus most of the milk produced in the country is either sold as fluid milk or processed using traditional practices using traditional clay pot churners. In many households, milk is accumulated in the clay pot and kept at room temperature for several days by adding fresh milk in to the already accumulated until is sour for processing. Because the small holder traditional milk processing is based on sour milk. A clay pot is then used to churn the sour milk to get butter and other products. Processing milk in to such stable and marketable product generates cash income for smallholders' producer in the rural areas and enable them to conserve milk solids as butter for sale and consumption (Lemma 2004).

Yet, the clay pot churners are not efficient either in their butter production, in saving time and labor. Studies indicated that the traditional method of churning is time consuming, perhaps, taking more than an hour (O conner et al 1993, Feyisa et al, 2009 and Yilma $Z$ et al 2007). O'Connor et al (1993) reported that in on-farm trails in the Debre Birhan areas, Ethiopia, an average churning time of 139 minutes. Likewise, Yilma $\mathrm{Z}$ et al (2007) reported 191 minutes for traditional clay pot churner while Feyisa et al (2009) reported $65 \mathrm{~min}$ on average when using the traditional clay pot churners in central rift valley areas of the country. Mahony and peters (1987) also reported that traditional clay pot churners give low yield butter per unit of sour milk and require high labor input. Similarly the amount of butter obtained from traditional milk churner is lower than the yield obtained from improved churner as reported by (Lemma 2004).

Nevertheless different on farm participatory type research activities were conducted by different institutions to try new types of churners by comparing their time saving potential and butter yield along with traditional clay pot churners. Studies conducted by O'Connor et al (1993) reported as 57 minutes was obtained with the agitator fitted into the traditional clay pot churner. In a related research conducted by Alganesh (2002), using the internal agitator reduced churning time by $22 \%$ from an average of 28 minutes to 23 minutes. The same author reported that the average butter obtained the internal agitator was 359.7 grams and 376.9 grams per 6 liters of sour milk, respectively. Yilma $Z$ et al (2007) also reported that $475 \mathrm{~g}$ of butter was obtained using clay pot with the churning time of 191 minutes (3.7hr) whereas $492 \mathrm{~g}$ of butter was obtained from internal wooden made agitator which is developed by International Livestock Research Institute (ILRI) with the churning time of 80 minute (1.3hr). The milk was churned after $62 \mathrm{hr}$ of fermentation and ten (10) litters of milk were used for both butter making methods (Yilma $\mathrm{Z}$ et al, 2007). 
In on farm trial made around Adami Tulu area of central rift valley of Ethiopia the average time taken by traditional milk churner was reported as $65 \mathrm{~min}$ and the modified milk churner which was wooden made was reported to be $43.54 \pm 5.06$ (Tesfaye et al.,2008). In the same place, but using different improved churner made from plastic (developed by Adami Tulu Agricultural Research) Feyisa et al (2009) reported reduced churning time by $58.89 \% \%$ from the average $80.97 \mathrm{~min}$ to 33.29 using traditional and plastic milk churner respectively.

In all the above research activities promising results have been found by using the improved milk churners. At Adami Tulu Agricultural research center the plastic milk churner evaluated by farmers also showed a promising result around Adami Tulu areas as reported by Feyisa et al, (2009) and Tesfaye et al. (2008). Yet this milk churners were not evaluated and demonstrated under farmers circumstances in milk producing areas of West Arsi zone. Therefore, this research and extension activity is proposed with an objective of demonstrating and evaluating improved plastic milk churner there by reducing women farmers' workload in churning activity in west Arsi zone.

\section{OBJECTIVES}

To demonstrate and evaluate improved plastic milk churner technology with women farmers in West Arsi zone

To reduce time spent and women farmers work load in churning activity

\section{Material AND Methods}

\section{Description of the Study Area}

The study was conducted in Shashamane and Kofele Districts of Oromia Regional State. Shashamane is located in West Arsi Zone, Oromia Regional State about 240km south of Addis Ababa lying on the main way road to Hawasa. Geographically, the area is located at $7^{0} 11^{\prime} 33^{\prime \prime} \mathrm{N}$ altitude and $38^{\circ} 35^{\prime}$ ' $33^{\prime \prime}$ E longitude. The area has an annual average temperature ranging from $12^{\circ} \mathrm{c}$ to $28^{\circ} \mathrm{c}$. The rainfall ranges from 1500-2000ml (OFEDO, 2009).

Kofole is also located in West Arsi Zone of the Oromia Regional State. The area has an altitude and longitude of $7^{0} 00^{\prime \prime} \mathrm{N} 38^{0} 45 \mathrm{E} / 7 \mathrm{~N} 38.750 \mathrm{E}$. The annual average rainfall of area is about $1232 \mathrm{ml}$ with a mean monthly rainfall of $102.6 \mathrm{ml}$. The mean monthly minimum and maximum temperatures are about $5.4^{\circ} \mathrm{C}$ and $19.8^{\circ} \mathrm{C}$, respectively (OFEDO, 2009).

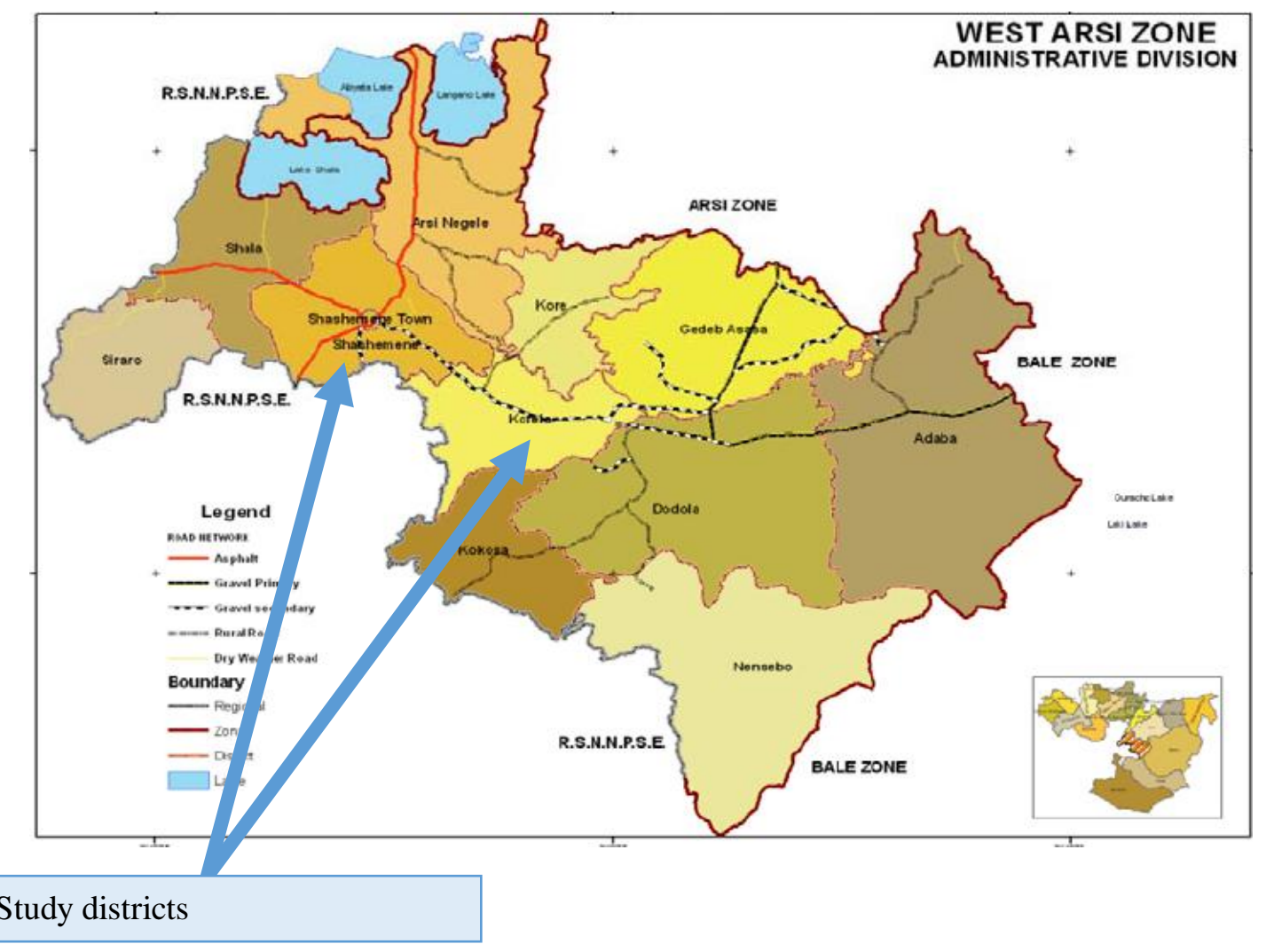

Figure 1. Map of the study area

Source: (OFEDO, 2009). 


\section{Farmers Selection and Group Formation}

The demonstration and evaluation of the churners used Farmers Research Group (FRG) approach. FRG approach is a participatory research approach whereby multidisciplinary team of researchers, extension workers, group of farmers and other pertinent actors jointly conduct research on farmers' field on selected topics (Bedru B et al, 2009).

Thus, Fifty three (53) and twenty nine (29) women farmers were selected for group formation or as a member of Farmers Research Groups (FRG) from Kofele and Shashemene districts respectively. The selection of kebeles was done purposively in collaboration with district experts from respected livestock and fishery development offices basing potential of the kebeles for their milk production potential.

Among 53 (fifty three) women farmers of Kofele district, three FRGs were established and from 29 twenty nine women farmers of Shashemenne two FRG's were established. From the established FRG's selected 10 and 7 farmers who had lactating cows during the study were selected as experimental or trial farmers from both districts respectively.

\section{Training}

Training was given to all participating women farmers to create awareness about improved plastic milk churners, the intended objective of the activity and to improve efficiency and quality of milk and dairy products production, handling and processing. The training was organized in both Shashamane and Kofale districts respectively at on-farm level for all FRG members and respective site development agent (DAs) and district extension agents.

\section{Extension Material Development}

Simple manual with the necessary steps while using the technology was developed by local language and distributed for each experimental farmers.

\section{Materials Used}

The materials used or compared were traditional clay pot churner which farmers have on their own hands and improved plastic milk churner produced by the project for the evaluation and demonstration purpose. Total of 18 improved plastic milk churner with 10 volumetric were produced at Guddina micro enterprise. Among those 18 milk churners 10 was distributed for kofale and 7 seven was also distributed for shashamane experimental farmers and one is left for Adami Tulu Agricultural research center as a sample.

Direction on methods of installation and operation of the newly designed plastic milk churner was given to the experimenting farmers.

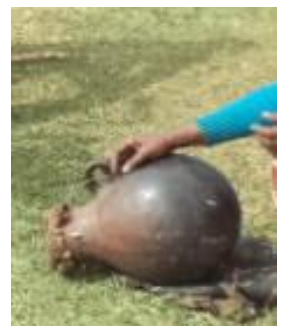

Traditional clay pot churner

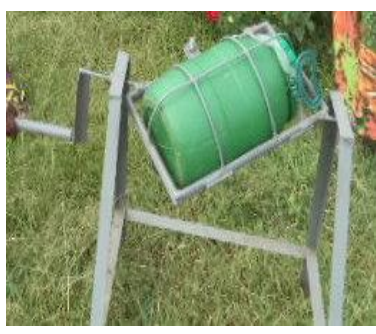

Improved plastic milk churner

\section{Data Collection}

Data collection sheet was prepared and distributed to the trial or experimental farmers and orientation was also given for farmers and DAs on data recording methods. The data sheets include amount of milk for each churning, time taken for agitation, time taken for churning, amount of butter obtained as well as types cow. The data collected included the type of churner used, amount of soar/fermented milk used, starting time of churning, ending time of churning, time taken to churn and butter yield

\section{Data Analysis}

For data analysis Excel worksheet and SPSS v20 were used. 


\section{RESULT AND DISCUSSION}

Seventeen (17) experimenting farmers from two Kebeles of kofale and shashamane districts, organized in farmer research group (FRG), were participated in the evaluation of improved plastic milk churner and traditional clay pot churner. Milk from both cross breed and local cows was used compositely for evaluations of the milk churners by the farmers after the milk was accumulated and fermented. The FRGs used time required for churning and butter production as criteria/parameters to compare the two churners. The capacity of the improved churners distributed was 10lt while the traditional clay pot churners could accommodate 5lt. Nonetheless, the average amount of milk used by the farmers for both milk churners was not more than 5lt. The following tables shows the results of the evaluation based on the data gathered from the farmers who evaluated both the churners comparatively.

Table 1. Difference in time taken to churn and butter yield among churners.

\begin{tabular}{|l|l|l|l|l|l|l|}
\hline \multirow{2}{*}{} & \multicolumn{5}{|l|}{ Improved } & \multicolumn{3}{l|}{ Traditional (clay pot) } \\
\cline { 2 - 7 } & TT $(\mathrm{hr})$ & BY(gm) & AMCh (lt) & TT (hr) & BY(gm) & AMCh (lt) \\
\hline Mean & $\begin{array}{l}0: 39 \pm \\
0.01\end{array}$ & $180.5484 \pm 6.46$ & $3.3065 \pm 0.078$ & $1: 05 \pm 0.01$ & $174.7742 \pm 8.07$ & $3.3065 \pm 0.08$ \\
\hline $\mathrm{N}$ & 62 & 62 & 62 & 62 & 62 & 62 \\
\hline $\begin{array}{l}\text { Std. } \\
\text { Deviation }\end{array}$ & $0: 12$ & 50.90772 & .61641 & $0: 15$ & 63.54485 & .63604 \\
\hline
\end{tabular}

$\mathrm{TT}=$ time taken $($ in $\mathrm{hr})$

$\mathrm{BY}=$ Butter Yield (in gm)

$\mathrm{AMCh}=$ Amount of milk churned (in lt)

As can be seen from table 1 above, using improved plastic milk churner reduced the time required for butter making by 26 minutes for the same volume of milk with a statistically significance difference in churning time $(\mathrm{p}<0.05)$ between the two churners. The time taken for churning using improved churner was recorded as $0.39 \pm 0.01 \mathrm{hr}$ while the traditional clay pot churner took 1:05 $\pm 0.01 \mathrm{hrs}$. Using the improved plastic milk churner was found to be improving the time efficiency up to $40 \%$ as compared to the traditional clay pot. This finding is comparable but slightly higher than with the finding of (Feyisa et.al.2009) which reported an average time of 20 minutes on the same type of churner with an efficiency of $58.89 \%$ at Adami Tullu area. The difference could be justified by the difference in environmental temperature, the hotter the environmental temperature the shorter the time taken for butter making.

Furthermore the churning efficiency, could also be affected by the amount of milk. Feyisa et.al.2009 reported that filling more than half of the volumetric capacity of the improved milk churner increases churning time recommending the optimum amount of milk to be used as 6.5lt for better efficiency of improved plastic milk churners. However, the max amount of milk used by the farmers in this study was 51t.

Nevertheless, the two churners didn't show a statistically significant difference $(p<0.05)$ in terms of their butter yield. The butter yield recorded for improved and traditional clay pot churners was $180.5484 \pm 6.4$ and $174.7742 \pm 8.07$ respectively.

The study also tried to see if there is a difference in churning time and butter yield among the churners across the two districts where the evaluation took place. The following table describes the result.

Table 2. Difference in time taken to churn and butter yield among the churners across district.

\begin{tabular}{|c|c|c|c|c|c|c|c|c|c|c|c|c|}
\hline & \multicolumn{12}{|c|}{ District } \\
\hline & \multicolumn{6}{|c|}{ Kofele } & \multicolumn{6}{|c|}{ Shashemenne } \\
\hline & \multicolumn{3}{|c|}{ Improved } & \multicolumn{3}{|c|}{ Traditional } & \multicolumn{3}{|c|}{ Improved } & \multicolumn{3}{|c|}{ Traditional } \\
\hline & $\begin{array}{l}\text { TT } \\
(\mathrm{hr})\end{array}$ & $\begin{array}{l}\text { BY }(\mathrm{gm} \\
)\end{array}$ & $\begin{array}{l}\text { AMCh } \\
\text { (lt) }\end{array}$ & $\begin{array}{l}\text { TT } \\
(\mathrm{hr})\end{array}$ & $\begin{array}{l}\text { BY(gm } \\
\text { ) }\end{array}$ & $\begin{array}{l}\text { AMCh } \\
\text { (lt) }\end{array}$ & $\begin{array}{l}\text { TT } \\
(\mathrm{hr})\end{array}$ & $\begin{array}{l}\text { BY(gm } \\
\text { ) }\end{array}$ & $\begin{array}{l}\text { AMCh } \\
\text { (lt) }\end{array}$ & $\begin{array}{l}\text { TT } \\
(\mathrm{hr})\end{array}$ & $\begin{array}{l}\text { BY }(\mathrm{gm} \\
)\end{array}$ & $\begin{array}{l}\text { AMCh } \\
\text { (lt) }\end{array}$ \\
\hline Mean & $\begin{array}{l}0: 4 \\
0\end{array}$ & $\begin{array}{l}185.871 \\
0\end{array}$ & 3.3065 & $\begin{array}{l}1: 0 \\
6\end{array}$ & $\begin{array}{l}186.580 \\
6\end{array}$ & 3.3065 & $\begin{array}{l}0: 3 \\
7\end{array}$ & $\begin{array}{l}175.225 \\
8\end{array}$ & 3.3065 & $\begin{array}{l}1: 0 \\
5\end{array}$ & $\begin{array}{l}162.967 \\
7\end{array}$ & 3.3065 \\
\hline
\end{tabular}


On-Farm Demonstration and Evaluation of Improved Plastic Milk Churner in West Arsi Zone of Oromia Regional State, Ethiopia

\begin{tabular}{|l|l|l|l|l|l|l|l|l|l|l|l|l|}
\hline \hline $\mathrm{N}$ & 31 & 31 & 31 & 31 & 31 & 31 & 31 & 31 & 31 & 31 & 31 & 31 \\
\hline $\begin{array}{l}\text { Std. } \\
\text { Deviatio } \\
\mathrm{n}\end{array}$ & $\begin{array}{l}0: 1 \\
0\end{array}$ & $\begin{array}{l}65.9493 \\
5\end{array}$ & $\begin{array}{l}0.5870 \\
5\end{array}$ & $\begin{array}{l}0: 0 \\
6\end{array}$ & $\begin{array}{l}79.4656 \\
2\end{array}$ & $\begin{array}{l}0.5870 \\
5\end{array}$ & $\begin{array}{l}0: 1 \\
4\end{array}$ & $\begin{array}{l}29.3549 \\
7\end{array}$ & $\begin{array}{l}0.6541 \\
8\end{array}$ & $\begin{array}{l}0: 2 \\
1\end{array}$ & $\begin{array}{l}40.0952 \\
9\end{array}$ & $\begin{array}{l}0.6913 \\
4\end{array}$ \\
\hline $\begin{array}{l}\text { Std. } \\
\begin{array}{l}\text { Error of } \\
\text { Mean }\end{array}\end{array}$ & $\begin{array}{l}0: 0 \\
1\end{array}$ & $\begin{array}{l}11.8448 \\
5\end{array}$ & $\begin{array}{l}0.1054 \\
4\end{array}$ & $\begin{array}{l}0: 0 \\
1\end{array}$ & $\begin{array}{l}14.2724 \\
5\end{array}$ & $\begin{array}{l}0.1054 \\
4\end{array}$ & $\begin{array}{l}0: 0 \\
2\end{array}$ & 5.27231 & $\begin{array}{l}0.1174 \\
9\end{array}$ & $\begin{array}{l}0: 0 \\
3\end{array}$ & 7.20133 & 0.1241 \\
7
\end{tabular}

TT= time taken

$\mathrm{BY}=$ Butter Yield

$\mathrm{AMCh}=$ Amount of milk churned

As shown on table 2 on average FRGs at both districts used of 3.3065 lit of fermented milk for the evaluation of the churners. The result indicate that the time taken to churn using improved churner as $0: 40 \pm 0.01 \mathrm{hr}$ and $0: 37 \pm 0.02 \mathrm{hr}$ in Kofele and Shashemenne districts respectively while the traditional clay pot churner took 1:06 $\pm 0.01 \mathrm{hr}$ and 1:05 $\pm 0.03 \mathrm{hr}$ in Kofele and Shashemenne respectively. In terms of butter yield the improved churner yielded $185.87 \pm 11.84 \mathrm{gm}$ and $175.22 \pm 5.27 \mathrm{gm}$ in kofele and Shashemenne respectively, while the traditional clay pot yielded $185.87 \pm 11.84 \mathrm{gm}$ and $162.97 \pm 7.2 \mathrm{gm}$ in Kofele and Shashemenne districts respectively with no differing amount of milk. As a result, both churners have shown no statistically significance difference $(\mathrm{p}<0.05)$ across districts in time taken and their butter yield.

Even though the results are not statistically significant across districts, the time efficiency difference between the two churners and butter yield with equal amount of milk could be associated with the cattle breeds, temperature differences among the districts which can differ the degree of agitation as explained by O Connor, (1994).

\section{Farmers' Response and Feedback}

In many districts of Ethiopia, Milk processing is the sole responsibility of females. Men don't process and/or involve in processing and marketing of milk and milk products. Study by Nicholson et.al (1999) indicated that more than $70 \%$ of the time spent in processing dairy products is covered by women or the female headed house hold. Lemma (2004) also reported that milk is mostly processed by women and girls and rarely by boys.

In the districts were this demonstration work took place, similar to the studies quoted above, churning is the responsibility of females and it can take from one and half hours to two hours depending upon their daily chores. Adult males in the study area do not churn as a result of the gender division of labor, the suitability of the churner and different cultural issues. However, as the demonstration took place with the presence of male household members including the husband, participating female farmer have showed interest on the improved churner especially in kofele district as it was found to be helpful in reducing the time of churning and its suitability to be used by men and boys.

\section{CONCLUSION AND RECOMMENDATION}

\section{Conclusion}

The study set out to demonstrate and evaluate improved plastic milk churners (improved churner and traditional clay pot churner). For the study, 17 trial female farmers grouped in FRG in two districts of west Arsi zone of Oromia regional state were involved. The improved plastic churners were produced in advance and the traditional clay pot churners already available on the farmers hand were used. Trainings were also prepared for all the trial farmers and other non-trial farmers including their husbands. Milk from both cross breed and local cows was used compositely for evaluations of the milk churners by the farmers after the milk was accumulated and fermented. The FRGs used time required for churning and butter production as criteria/parameters to compare the two churners.

The result indicated that a significant difference in churning time at $(\mathrm{p}<0.05)$ among the two churners. But there was no statistically significant differing in butter yield with equal amount of fermented milk between the two churners in both districts. Furthermore the study has created demand as the participating female farmer have showed interest on the improved churner. However, the study lacked in analyzing how women farmer spent their saved time which was previously consumed through 
churning by traditional clay pot churner. Nevertheless, based on the results, it can be concluded that the improved churner was found to be more time saving than the traditional clay pot churner.

\section{RECOMMENDATION}

Based on the results found the following recommendations are given

Further assessment is needed to analyze analyzing how women farmer spent their saved time which was previously consumed through churning by traditional clay pot churner

The perception of our farmer especially in kofale districts regarding to the technology is good and still there is demand for additional improved plastic milk churners. Thus, further scaling up activity is recommended. To this end, considering linkage among stakeholders for the multiplication and promotion of the technology is important

\section{REFERENCES}

[1] Alganesh T., Tesfaye L., Chernet A. and Mulugeta K. (2001). Introduction of ILCA internal agitator for increasing the efficiency of traditional butter making. Proceeding of $9^{\text {th }}$ annual conference of the Ethiopian Society of Animal (ESAP) Addis Ababa. Ethiopia. August 30-31. 2001 pp 135-144.

[2] Bedru B., Berhanu S., Endeshaw H., I. Matsumoto, M. Niioka, K. Shiratori, Teha M. and Wole K. (2009). Guideline to Participatory Agricultural Research through Farmer Research Group (FRG) for Agricultural Researchers. FRG Project, EIAR, OARI and JICA.

[3] Feyisa Hundessa Tesfaye Lemma and Esayas Assefa. (2009). Demonstration and Evaluation of plastic made improved milk churner in Adami Tulu District of East Shewa. FRG project 2009 FRG completed research reports 2009.

[4] Lemma F. (2004). Assessment of butter quality and butter making efficiency of new churners compared to stallholder's butter making techniques in East Shewa Zone of Oromia Ethiopia. MSc thesis. Alemaya University. Alemaya. Ethiopia.

[5] Mahony O. F. and Peters. B. (1987). Sub-Saharan Africa -Option for smallholder milk processing. Food and Agricultural Organization of the United Nations. World Animal Review no.62, pp 16-30.

[6] O'Connor C. B., Mezgebu S and Zewdie Z. (1993). Improving the efficiency of butter making in Ethiopia. Retrieved from http://www.fao.org/docrep/V1650T/v1650T0m.htm

[7] O'Connor C. B, (1994). Rural Dairy Technology. ILRI training manual 1. ILRI (International Livestock Research Institute) Addis Ababa. Ethiopia pp .13

[8] Oromia Regional State Finance and Economic Development Office (OFEDO) (2009). West Arsi zonal Map.

[9] Mahony O. F and Ephraim. B. (1985). Traditional butter making in Ethiopia and possible improvement. ILCA Bulletin No. 22.

[10] Tesfaye Lemma. Estefanos Tadesse and Wole Kinati. (2008). Evaluation and demonstration of improved milk churner to FRG around Adami Tulu District. FRG Project 2008. FRG completed Research reports 2008.

[11] Yilma Z. Loiseau G and Faye B. 2007. Manufacturing efficiencies and microbial properties of Ethiopian milk products; butter and Ayib- Ethiopian cottage cheese. Livestock Research for Rural Development, 19(88) 